\title{
Folktale Si Layung and Si Kohkol as Water Conservation Media in Multimedia Era
}

\author{
Ridzky Firmansyah Fahmi, Syihabuddin, Sumiyadi \\ Postgraduate Program, Indonesia University of Education \\ zhukhie@gmail.com
}

\begin{abstract}
The availability of water resources is central to human life. Water resources utilized by humans must be maintained its availability until the future in order to be enjoyed by the next generation. Efforts to maintain the availability of water resources is done by care, maintain, and use it wisely. Such conservation efforts can be done through traditional things through folktale. Folktale has a high content of wisdom and philosophy. Folktale serves as an entertainer, an analogy, and as a social system of society. To describe the relevance of folktale and the system of social institutions governing the way of life/behavior of the community with the use of water, an analytical descriptive method with a micro ethnography approach focusing on a smaller cultural sphere is selected. This method is chosen to provide an overview of the patterns of life and behavior of people who are influenced by elements of the story that develops with the conservation of water resources. The story that used as data is the folktale about $\mathrm{Si}$ Layung and $\mathrm{Si}$ Kohkol who is the guardian of Situ Gede and Situ Cibeureum, Tasikmalaya. The results of the study found the findings that folktale can be an easy and natural conservation medium for the community. In the multimedia era, the role of oral literature is still ranked as the main media for education as an effort to conserve water resources. Medium of orally in folktale can be an effective community-based learning media in the awareness and learning of ecosystem management. Documentation of folktale in the form of research describes the concept of natural balance contained in it. This study focuses on studying the function of folktale as a medium for conservation of water resources for the community. The existence of water resources in Tasikmalaya serve as a source of irrigation rice fields and fishery land to meet the needs of community life.
\end{abstract}

Keywords-folktale Si Layung and Si Kohkol; conservation of water resources

\section{INTRODUCTION}

Water and forest become an important element in life for the Sundanese. Sundanese assume that water is heaven and earth is the land. Earth's element is in the forest that gives the harvest for life and water provides life by fertilizing the soil and becomes an essential element in various rituals. Water is a blessing, sacred, holy, and pure. Each blessing is associated with an event that does not come from human experience but comes from a god. That is why Patanjala is known as the God of Rain in Sundanese society. In addition, water is characteristic of naming places in the Sunda region. Sudaryat affirmed Wittfogel's opinion that the number of place names that began with the word $c i$ made the Sundanese community as a water society. This can be seen from several names of places in the Sunda region beginning with the word $c i$ (meaning water), among them Ciamis, Cimahi, Cirebon, Cicalengka, Cibeureum, and Cihideung (Sudaryat, 2015, pp. 52-53).

Water is a blessing that will bring sustainable living in the world. That is why water must be maintained so that its availability continues in the future and can be enjoyed by the next generation. Water maintenance efforts are done by many parties in various regions, such as in Kampung Kuta, Ciamis, West Java by applying the rules of using water resources for daily needs and ritual purposes. Water used for daily purposes is piped through the structures. While the use of water resources used for ritual purposes is only used for village ritual events and should not be used for everyday purposes. In addition, there are forests that are sacred and function as conservation land because the water resources are in the forest. This makes the existence of water resources preserved and there is no excessive use for everyday purposes (Aulia, 2011, pp. 347). Meanwhile, efforts to conserve water resources by implementing a pro environmental behavior change program were conducted in Miami, Florida. Water resources conservation is carried out by applying water demand management strategies covering three things: economics, technology, and behavior. The demand management strategy is done through water meter, efficiency device program, water efficiency labeling, educational program, and water leak control through various applications (Lee, 2013, pp. 683). Liu (2015) examines the conservation of water by disseminating information through various mediums, such as brochures, posters, and websites. Liu's research is a conservation effort involving government and environmental organizations.

Aulia's research focuses on water resource management systems through customary rules (pemali). Lee's research focuses on conservation efforts with water demand management programs through efficiency and restrictions on water use 
in residential environments. Liu's research focuses on information media in disseminating water resources conservation information. Aulia focuses on the growing value functioning in the community as water conservation while Lee focuses on the control of water use in housing using meter and government programs. Likewise with Liu who focuses on conservation efforts by optimizing the use of multimedia such as brochures and websites in the dissemination of information on water conservation efforts in housing.

This research is based on folktale of lake guard fish in Tasikmalaya area. From the research results found that the folktale serves as a social institution as well as efforts to conserve water resources in Tasikmalaya. The existence of stories about the lake guard fish to make the community to keep the area around the lake and not doing exploitative activities with the use of lake water.

\section{METHODS}

This research employed qualitative design as the ground theory of oral literature and concept of balance nature. The method used in the research was ethnography, using natural environment as the direct source of data, with analytical descriptive and native's point of view-based in nature (Biklen, 1982, pg. 27-29; Sibarani, 2012, pg. 268). The type of ethnography utilized in this research was micro ethnography focusing more on a smaller group of culture, a society group near the research area.

In order to gain the data, two types of instruments were involved, including observation and interview. The observation was conducted in Situ Cibeureum and Situ Gede (situ is similar to lake), Tasikmalaya, while the interview was implemented to two caretakers of a sacred place or known as kuncen of Situ Cibeureum named Mr.Atang (73 years old) and of Situ Gede named Mr. Herman (53 years old). The research was done ethnographically because society's knowledge can be realized from the form of culture constituting high values used as the life bases. These life bases are communal identity researched through a method aiming to see the pattern of society's behavior in daily life that has made folklore as a medium of water source conservation.

\section{Folktale of Si Layung and Si Kohkol}

\section{FINDING AND DISCUSSION}

The myth of Si Layung and Si Kohkol are found in two lakes in Tasikmalaya, Situ Gede and Situ Cibeureum. Situ Gede story begins with Eyang Prabu Dilaya who spreads Islam in Tasikmalaya area and is very happy to learn the science of religion so forget his two wives. One night, the two wives agreed to kill the Eyang Prabu Dilaya and his body was buried in the middle of the river. Over time the river water overflowed but did not soak the tomb of Eyang Prabu Dilaya. To guard the tomb, Eyang Prabu Dilaya's mother ordered two soldiers turned into fish named Si Layung and Si Kohkol. While the story Situ Cibeureum stems from the dream of Ki Bagus Djamri who gets the order to create a large pool and flower garden in the middle. The next morning, Ki Bagus Djamri realizes the command in his dream. He also made a pond and flower garden in the middle of the pool. Over time the pond water overflowed but did not flood the flower garden. Finally the pond became a lake and guarded by Si Layung and Si Kohkol.

Both lakes are guarded by two fish that are the type of goldfish (Si Layung) and cork (Si Kohkol) which is said to be the size of a cupboard/door. Various prohibitions accompany the story of Si Layung and Si Kohkol, among them should not speak harshly, should not be arrogant, not make noise, do not pollute the lake area, and do not do immoral acts around the lake. If the rule is violated, the lake water turns reddish which means Si Layung and Si Kohkol will appear and make the breaking visitors get the bad luck.

\section{Conservation of Water Resources in the Multimedia Era}

The conservation of water resources is an effort to maintain the existence and sustainability of the state, the nature and function of water resources in order to be within the quantity and quality appropriate to meet the needs of living things, both present and future. Nature needs to get attention so that resources are not exhausted and there is no natural damage. The depletion of resources indicates dissonance and injustice for the survival of natural resources and for future generations. Water resources that can be managed and utilized by humans are sea water, rainwater, groundwater, and surface water. Surface water is the freshest type of freshwater used by people to meet daily needs and is available in springs, rivers, lakes, and reservoirs. Surface water management and utilization shall be carried out in order to keep its availability sustainable. One of the efforts done is to arrange the space with the development of natural resource fields. Spatial planning is done as a form of conservation of surface water sources in the areas of rivers, lakes, reservoirs, swamps, water catchments, forests, and beaches. Several conservation efforts take account of cross-administrative and functional approaches through the reforestation of critical land, mangrove plantation and mangroves in swamps and coastal areas, wise management of lake 
water systems for agricultural and fishery lands, and restructuring of land around resources water (Undang-undang Republik Indonesia No. 7, 2004, pp. 4, Undang-undang Republik Indonesia No. 24, 1992, p. 2, Dharoko, 2006, pp. 92; Lubis, 2006, pp. 29; Asefa, 2014, p. 9).

With the efforts to conserve water resources, the reactualization of the community's traditional values in protecting the environment has been done in the area around the lake in Tasikmalaya. Conservation of water resources is done in the form of traditional reactualization values by way of animating the story that developed in the area through the story of the lake guard fish that is Si Layung and Si Kohkol. The conservation of water resources through folktale has the utility for the community as in the aspects of cultural values and norms that are regarded as the behavioral guides that determine civility: virtue, politeness, harmony, and so on. Folktale contains lessons and religions as well as social norms emerged as the basis of interrelated attitudes and meanings. The selection of stories serves to symbolize and project values in social life (Udu, 2013, p. 201, Merchant, 2016, p. 5).

Folktale still occupies an important role in the values and social control in society in today's multimedia era. In the multimedia era, multimedia technology became an effective tool for focusing information dissemination (Wang, 2011, pp. 3164). Various technological developments and learning media use multimedia as a medium to achieve more effective learning objectives with a wider coverage range. But unlike the community groups living around the lake that does not make multimedia as a medium of environmental education. Orally which is still a medium of learning the special knowledge in the management and utilization of the environment (water resources) through the story of the lake guard fish. In the era of multimedia, folktale still displays a mythological pattern that serves as the inner guidance of the human subconscious. Stories are universal levels of communication that increase audience engagement, help listeners understand reality, and convey ideas more effectively (Merchant, 2016, pp. 1).

The story of the people of Si Layung and Si Kohkol is still used by people in Tasikmalaya as a system of social institutions and intergenerational educational media, defeating the use of other educational medium which is limited and dependent on facilities and infrastructure. Although society has transcended modern times, the story is still inherent and "nurtured" as a norm in social life especially in traditional society. Do not say rude, being arrogant, and littering the lake is a practical way of the ancestors in maintaining the natural environment (lake) to remain sustainable and clean so that created the story of fish guard in relation to lakes. The restrictions contained in the story of Si Layung and Si Kohkol were made to prevent the avalanche of landslides, floods, droughts, and climate change due to the disturbance of the natural environment. The ban builds the human consciousness of its relationship with nature and builds a civilized character. The harmony of life between man and nature can be created when man is conscious of his existence which is part of the universe.

Utilization of water resources is done wisely through the inventory of folktale that impact on social institutions and its relation to the environment as a medium for conservation of water resources. Water conservation behaviors correlate with positive attitudes toward water conservation, social support (norms), and behavioral control (Lee, 2013, pp. 683). Social norms are not always present in the form of legalized rules, but can be present through various mediums, such as folktale or in superstitious form. Various mediums in the form of stories and superstitions are created to insert social values and norms in mythic society culture. Conservation of water resources through folktale acts as a resource-based economy and as a support system of life (life support system). Natural resource management should be based on its role as a capital of economic growth and sustainability of the living system that has an impact on improving the economy of the people. In general, the effort that can be made in creating the sustainability of natural resources is the dissemination of Accessed to information related to the maintenance of natural resources; management and conservation of integrated natural resources; prevention of damage to natural resources in various forms such as environmental rescue action and installation of appeals in the form of posters; arrangement of social order in society; firm law enforcement against violators of natural resource conservation; as well as increased community involvement in the management and utilization of natural resources. Conservation efforts through folktale not only encourage community awareness in maintaining the lake ecosystem but also serve as a source of information for the culture of the community (Undang-undang Republik Indonesia No. 32, 2009, pp. 9; Nahib, 2011, p. 123).

In relation with water as a resource that indicates the balance of nature, Sundanese have a view of life that reflects the harmonious relationship between man and nature. The view of life is divided into several categories of relation with interaction object of which is related to himself and nature. The human view of himself is seen from obedience to the teacher and the teachings of the ancestors, upholding the advice of parents, teachers, and leaders, and believing in the pemali or ban. Humans have value to identify themselves as beings who have rules of life and follow the path that has been taught by the ancestors (parents, teachers, and leaders). In relation to nature, Sundanese believe that the world is inhabited by various kinds of beings, both evil and good. To maintain a natural balance between the influence of both types of creatures, then all human motion and behavior must be controlled. Prohibitions are created as ethics that every individual needs to adhere to in order for the interaction between two realms to remain (Warnaen, 1987, pp. 196-204). The custom 
rules that the people obey are a reflection of the human consciousness that man does not live alone and this universe is not just human. Various living things depend on the universe. The balance of nature as the living place of various beings must be maintained so that the relationship of the creatures is in harmony and harmony. The belief in the creatures that preserve the living environment is manifested by obeying various restrictions and respecting in its own way (such as performing rituals) to keep the environment sustainable and not disasters that affect human survival.

Geographically, Tasikmalaya is in a zone susceptible to natural disasters such as floods, landslides, hurricanes, and earthquakes. To anticipate the magnitude of the impact of the disaster, an environmental maintenance method is based on Tasikmalaya's geographic condition. In Tasikmalaya itself there are five lakes that functioned as a source of water and water reservoir during the rainy season. Of the five lakes, two of them have the same story related to the lake guard fish that is $S i$ Layung and Si Kohkol. Folktale is a medium of environmental maintenance because the people around the lake and lake visitors are encouraged to obey the rules that have become social institutions in the area. Maintenance of environmental spatial based on folktale is the use of the concept of sustainable living (eco-efficiency). In the concept of eco-efficiency, people are already thinking and implementing environmental management optimally so that current needs are met well and future needs are considered together (Purnama, 2014, pp. 4). Spatial patterns that take into account geographical conditions, causing the lake area to be safe from various disasters and to balance the surrounding ecosystems. In addition to the story of the lake guard fish, there are also forbidden forests and tombs that are sacred (tomb of Eyang Prabu Dilaya in the middle of Situ Gede and Ki Bagus Djamri tomb around Situ Cibeureum) which also become ecosystem maintenance medium because society will not disturb/damage the respected area.

In the life order of indigenous peoples, human relationships with nature are relationships based on relational relationships, kinship, respect, and love. The Sundanese believe that the universe is inhabited by various creatures, both evil and good. All human actions and behavior must be controlled so that the balance of nature between two creatures' influences can be preserved. Various restrictions were created in the form of stories. In human relationships with nature, folktale used as a conservation medium because it can provide knowledge in relation with natural phenomena that result in humans have rules and strategies in addressing these symptoms. The human and natural relationships that exist because of the beliefs in the form of folktale, show the relational relationships that are beneficial to human life in maintaining the natural environment. As well as on environmental management of waterfall (curug) and forest areas. Forest area is believed to be a gift or deposit from an ancestor that should not be disturbed by humans, that is why it is named leuweung titipan. Leuweung titipan also referred to as leuweung sirah cai that show respect to the ancestors and knowledge in water management because the forest is a water absorption area as well as natural water sources. If the forest is damaged, the water supply will be disrupted, and the survival of human life will be disrupted as well. Local people are the best ecosystem guardians through local knowledge and institutions. Local knowledge and institutions reflect and shape the ways of world governance and serve as the information base of a society. Conservation awareness towards community-based conservation is a strategy in conserving the natural environment to control natural resources and improve the economic well-being of the people in the multimedia era (Lamis, 1999, pp. 218; Kreps, 1999, p. 533).

In this multimedia era, information and communication technology is present in almost every aspect of life and becomes a medium in the educational system (Dina, 2014, p 246). But conservation efforts through folktale should not use the medium of information technology. The conservation of water resources through orally still function well in ecosystem education. The educational system in the multimedia era should not ignore the superstitious medium. Not all information technologies inspire and change people's behavior patterns, as in some community groups, information technology is not the main medium for information dissemination. Education can be done anywhere, through any medium. Not limited to information technology that requires technological devices that qualified in operation. In this multimedia era, orally still play an important role in the dissemination of information. In indigenous peoples, the dissemination of information through oral is an easy dispersal medium. Folktale is widely spread using the grace, although it can already utilize information technology in its dissemination, but the orally still considered important and valid in terms of scientific study.

\section{SUMMARY}

In the era of multimedia or we known as the term information society that refers to people who interact with technology and bring change of views in social institutions (Goodova, 2015, pp. 954). This society is not merely relying on multimedia as the medium of education and information dissemination. Folktale spoken orally, without using the medium of multimedia technology in the contemporary era, serves as a keeper of the traditional value of: conservation of water resources. The main causes of water resources conservation behavior are attitudes, beliefs, habits, and contextual forces (Lee, 2013, p. 683). Folktale reflects attitudes, beliefs, and has a contemporary meaning related to the efforts of saving ecosystems for the conservation of water resources. 
With the development and progress of a sustainable society, new media forms will emerge (Jinglei, 2012, p. 733). But the genius in folktale still will not die. Folktale will continue to grow and be sustainable because it has the value of a contextual tradition and its flexible form of dispersal enabling folktale with its grace can still live in various eras. Folktale has a wisdom manifested in the form of behavior that accompanies the folktale of Si Layung and Si Kohkol. This indicates the existence of the concept of nature preservation with the balance of nature in the folktale. Conservation awareness space through folktale is a form of folktale preservation that cannot be separated from cultural preservation because it has great potential to be a driver of sustainable conservation.

\section{References}

Asefa, T. dkk. (2014). "A tale of integrated regional water supply planning: Meshing socio economic, policy, governance, and sustainability desires together", Journal of Hydrology. Online: http://dx.doi.org/10.1016/j.jhydrol.2014.05.047 (Accessed on 28 July 2017)

Aulia, T.O.S \& Arya H.D. (2011). "Kearifan lokal dalam pengelolaan sumberdaya air di Kampung Kuta". Sodality: Jurnal Transdisiplin Sosiologi, Komunikasi, dan Ekologi Manusia, Vol. 4, No. 3.

Biklen, B. (1982). Qualitative research for education: an introduction to theory and methods. Sydney: Allyn and Bacon, Inc.

Dharoko, A. (2012). "Model arahan pemanfaatan lahan untuk konservasi sumber daya air di Kabupaten Sleman”. Jurnal Manusia dan Lingkungan, Vol. 13, No. 2: W-99. Online: http://jpeces.ugm.ac.id/ojs/index.php/JML/article/view/312/237 (Accessed on 12 January 2017).

Dina, A. T. \& S. I. Ciornei. (2014). "Teaching less widely used languages with qualitative multimedia". Procedia - Social and Behavioral Sciences, Vol. 128, $246-250$.

Goodova, M. (2015). "Multimedia Resources as Examples of Polymorphic Educational Hypertexts in the Post-Literacy Era". Procedia - Social and Behavioral Sciences, Vol. 214, 952 - 957.

Jinglei, N. (2012). "Multimedia Fusion Era Editorial Role”. Physics Procedia, Vol. 25,733 - 736.

Kreps, C. (1999). "Program pembangunan Museum Rakyat Kayan Mentarang: kebudayaan, pelestarian, dan partisipasi masyarakat" dalam Kebudayaan dan pelestarian alam: penelitian interdisipliner di pedalaman Kalimantan (Ed. Cristina Eghenter). Jakarta: WWF Indonesia.

Lamis, A. (1999). "Pola-pola penguasaan hak atas tanah pada tiga suku bangsa Dayak Kenyah" dalam dalam Kebudayaan dan pelestarian alam: penelitian interdisipliner di pedalaman Kalimantan (Ed. Cristina Eghenter). Jakarta: WWF Indonesia.

Lee, M. \& B. Tansel. (2013). "Water conservation quantities vs customer opinion and satisfaction with water efficient appliances in Miami, Florida". Journal of Environmental Management, Vol. 128, 683-689.

Liu, A. (2015). "Urban water conservation through customised water and end-use information". Journal of Cleaner Production, 1-12.

Lubis, R.F. (2006). "Air sebagai parameter kendali dalam tata ruang”. INOVASI. Vol.7/XVIII, June Persatuan Pelajar Indonesia.

Merchant, A. (2016). "Cross-cultural folk-tale-elicitation research on the perceived power, humanistic and religious symbolisms, and use of money". Journal of Business Research, 1-7.

Nahib, I. dkk. (2011). "Pengembangan valuasi ekonomi terumbu karang spasial dengan sistem informasi geografis dan metode benefit transfer (studi kasus Terumbu Karang di Kepulauan Karimunjawa, Jawa Tengah)”. Globë, Vol. 13, No. 2. Online: file://C:/Users/User/Downloads/94-148-1-SM.pdf (Accessed on 28 January 2017).

Purnama, E.S.M. (2014). "Identifikasi potensi dan kendala Kampung Naga sebagai kawasan strategis cagar budaya di Kabupaten Tasikmalaya".

Online: http://ejournal.unpak.ac.id/download.php?file=mahasiswa\&id=790\&name=EGI\%20SYAHRIL\%20MULIA\%20 PURNAMA\%20(052109007)\%20(ok).pdf (Accessed on 12 March 2017).

Sibarani, R. (2012). Kearifan lokal: hakikat, peran, dan metode tradisi lisan. Jakarta: Asosiasi Tradisi Lisan.

Sudaryat, Y. (2015). Wawasan kesundaan. Bandung: Jurusan Pendidikan Bahasa Daerah, Fakultas Pendidikan Bahasa dan Sastra, Universitas Pendidikan Indonesia.

Udu, S. (2013). "Tradisi lisan sebagai media konservasi lingkungan dalam masyarakat Wakatobi" dalam Folklor dan Folklife dalam Kehidupan Dunia Modern (Ed). Endraswara). Yogyakarta: Penerbit Ombak.

Undang-undang Republik Indonesia No. 7 tahun 2004 tentang sumber daya air. Online: https://www.google.co.id/search?q=situs+resmi + uu+no+7+2004+tentang + sumber+daya+air\&oq $=$ situs + resmi + uu 
+ no $+7+2004+$ tentang + sumber + daya + air \&aqs $=$ chrome.. $69 \mathrm{i} 57.17594 \mathrm{j} 0 \mathrm{j} 4 \&$ sourceid $=$ chrome $\& \mathrm{ie}=\mathrm{UTF}-8 \#$ (Accessed on 05 January 2017)

Undang-undang Republik Indonesia No. 24 tahun 1992 tentang penataan ruang. Online: http://www.pu.go.id/uploads/services/2011-11-29-12-2955.pdf (Accessed on 05 January 2017)

Undang-undang Republik Indonesia No. 32 tahun 2009 tentang perlindungan dan pengelolaan lingkungan hidup. Online: http://175.184.234.138/p3es/uploads/unduhan/UU_32_Tahun_2009_(PPLH).pdf (Accessed on 05 January 2017)

Wang, M. (2011). "On the Application of Multimedia Arts in the Exhibition Industry in the Computer Era". Procedia Engineering, Vol. 15, $3164-3168$.

Warnaen, S. (1987). Pandangan hidup orang Sunda seperti tercermin dalam tradisi lisan dan sastra Sunda. Penelitian Tahap I. Bandung: Bagian proyek Penelitian dan Pengkajian Kebudayaan Sunda, Direktorat Jenderal Kebudayaan Departemen Pendidikan dan Kebudayaan. 